\title{
技術者倫理教育に関する実態調查報告
}

\author{
Survey on Practices of Engineering Ethics Education
}

\author{
小 林 幸 人¹ \\ Yukito KOBAYASHI
}

1.はじめに

近年，我が国においても，技術者倫理教育の重要性 が認識され，各教育機関で実施されるようになってい る. 日本工学教育協会では, 平成12年の第 1 回から, 平成19年までに計 7 回のワークショップ「技術者倫理」 を開催してきた。 ワークショップでは，技術者倫理教 育の意義, 問題点に関する意見交換から授業計画の策 定などの実践的な試みが行われ，その成果は各教育機 関における教育実践に活かされている.しかしながら， 我が国における技術者倫理教育は未だ端緒についたば かりであり,依然として検討すべき課題は少なくない.

本調査は, 上記ワークショップ参加経験者を中心と した「技術者倫理Interest Group」のメンバーを対象 として, 技術者倫理教育の現状と課題を把握する目的 で実施されたものである．回答者は技術者倫理教育に 対して関心を持っているか，または技術者倫理教育を 担当もしくは担当を予定している者である. それゆえ， 本報告では比較的進んだ取組を行っている教育機関の 実施状況およびその課題を把握し，より効果的な教育 手法の開発に資することを期待するものである. 特に, EAC (Ethics Across the Curriculum), つまり全教 育課程を通じた倫理教育の可能性について検討を行う ことを主たる目的としている.

\section{2. 調査の概要}

調査は以下の要領で実施した.

調查実施者 : (社)日本工学教育協会

調査対象者：「技術者倫理 Interest Group」参加者

調查方法：メールによるアンケート調査

調查期間：平成18年 6 月 9 月

回答数：64名（約 320 名中）

なお, 途中集計結果について, 第55回工学・工業教 育研究講演会（平成18年 8 月北九州）で報告を行って いる.

本調查にご協力いただいた方々には心よりお礼申し 上げます。

平成 19 年 6 月 25 日受付

※ 1 八代工業高等専門学校

$※ 2$ 金沢工業大学科学技術応用倫理研究所

\author{
札 野順 $* 2$ \\ Jun FUDANO
}

\section{3. 調査結果}

アンケート質問項目および回答結果について資料1 に示す. 寄せられた回答結果に基づき, 技術者倫理教 育の実施状況および課題について述べる.

\section{1 技術者倫理教育の実施状況 \\ (1) 技術者倫理系科目の開講状況}

調査対象者の関心が高いこともあり，ほとんどの教 育機関で技術者倫理系科目が開講されている（問 1 ). 開講の理由としては,「技術者にとって不可欠な能力 であるため」という理由が多く, 倫理教育が技術者教 育において中核的な内容であるとの認識があることが 分かる. その一方で, JABEEへの対応という回答も 多くみられた（問 3 ). 主として技術者倫理を扱う科 目における学習・教育目標の設定に関する質問項目 (問 5 (7)）ともあわせ，技術者倫理教育導入の直接の動 機がJABEE対応という実際上の理由であることがう かがえる.

（2）技術者倫理を主として扱う科目の実施状況

実施形態としては，技術者倫理を主として扱う独立 科目を開講しているところが多いが，それに加えて複 数科目で倫理的内容を取り扱っているところもみられ る(問 4 )。ただし, これを大学および高専とで比較 すると, 高専では $70 \%$ 以上が独立科目での実施である のに対し, 大学では $50 \%$ であり, また独立科目を開設 せず, 複数の科目で扱っている場合もみられる(図 1 ).

技術者倫理を主として扱う科目の開講形態について は，必修科目としているところが $60 \%$ を超える（問 5 (1)). これも, 大学と高専を比較すると, 大学では選 択科目としているところもみられる (図 2). 開講期 間別では半期科目としての開講が最も多く, また, 開 講学年は 3 年次が最も多かった．担当者については, 1 名による授業が多いが, オムニバス形式を含む複数 担当者による授業も少なくない（問 $5(5)$ ). 理工系教 員（常勤）が担当する場合が多いが，この傾向は特に 大学にみられ, 逆に高専では人文社会系教員 (常勤) が担当するケースも多く見られる（図 3 ).

（3）授業方法㧍よび評価について

授業方法については講義形式が多く, 討論やディ ベートなど学生参加型の授業については, 受講者数が 多い大学では難しく, 比較的少人数の高専などで実施 

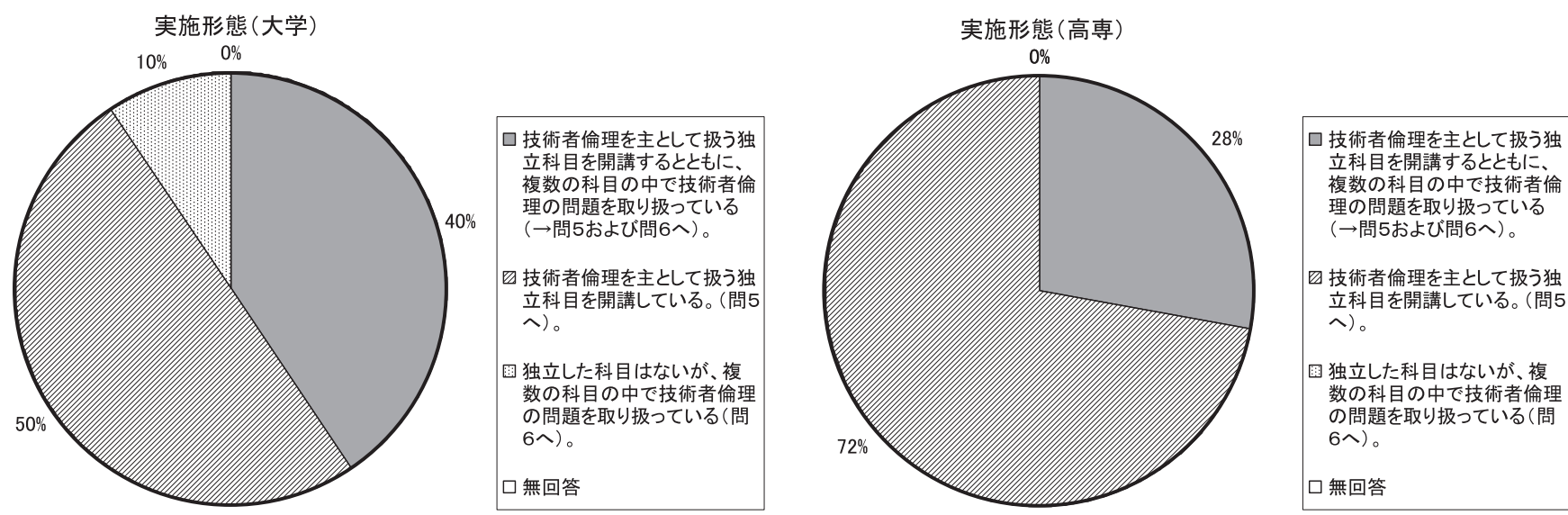

図 1 実施形態比較（大学および高専）
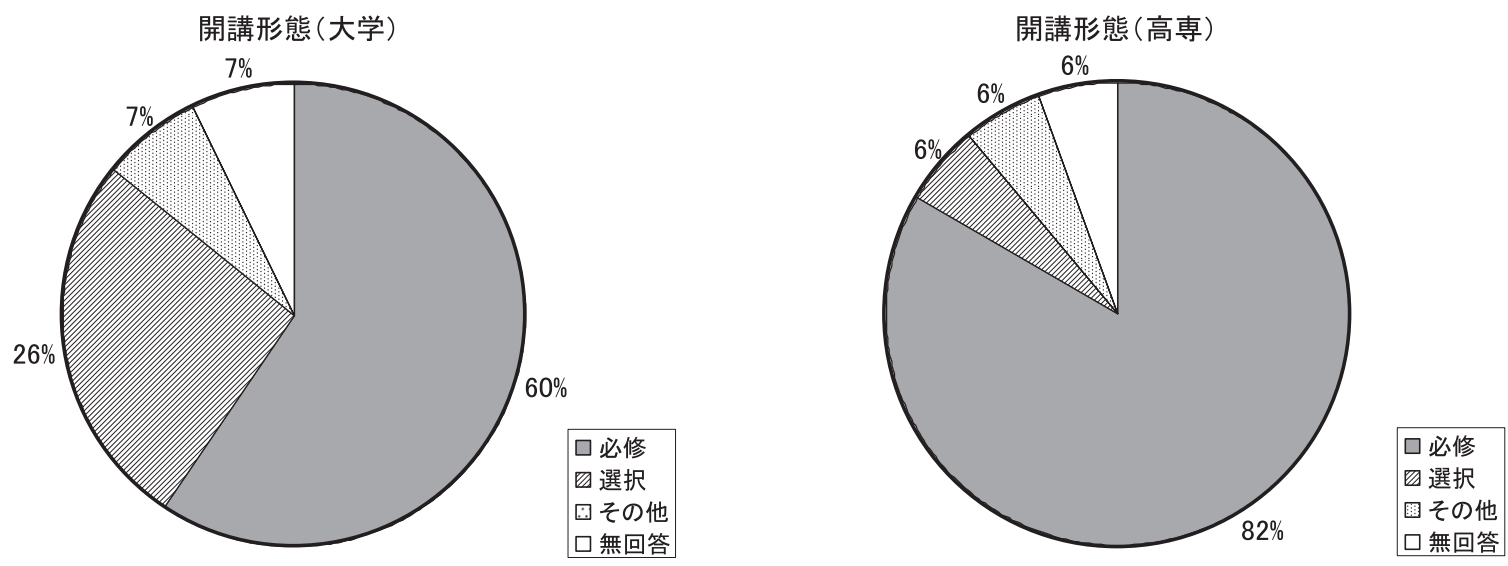

図 2 開講形態比較（大学および高専）

授業担当者(大学)

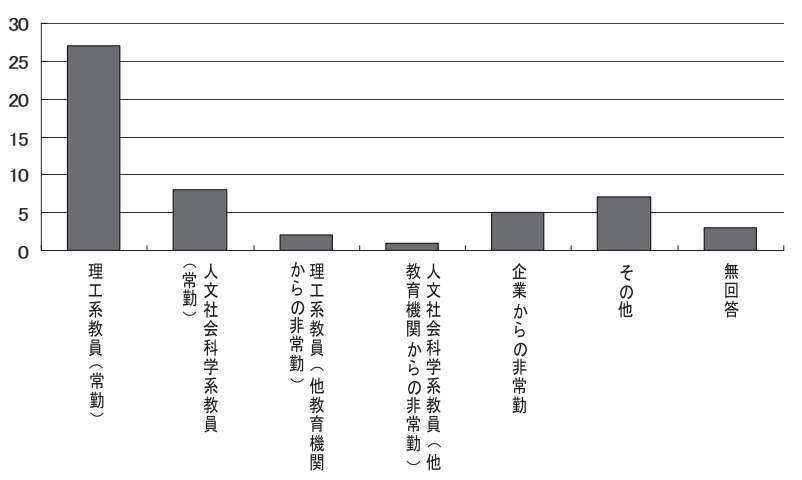

授業担当者(高専)

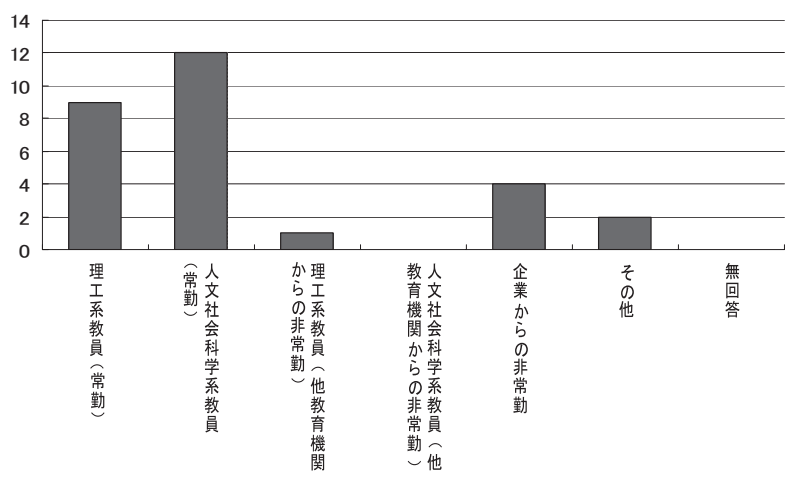

図 3 授業担当者比較（大学および高専）

されている，授業形式にかかわらず，事例を用いた教 育が重視されている (問 7 )。技術者倫理教育が知識 を享受するだけでなく, 分析力・判断力を養うことを 目的としていると理解されているためではないかと思 われる。これは, 成績評価の方法・観点とも関連して おり，多くの教育機関でレポートを用いて，「分析力」 「総合的な判断能力」という観点から評価が実施され ている（問 $9(1),(2))$. 回答からは, その他にも様々 な方法・観点から成績評価を行おうとしていることが 読み取れ，技術者倫理の教育成果の測定について様々 な試みがなされていることがうかがえる。
（4）実施上の問題点

授業を実施するにあたり，最も問題とされているの は成績評価の難しさである（問10）。技術者倫理教育 において, 分析力や判断能力を重視されているのは上 述したとおりであるが，これをどのように測定するの かについて明確な方法・基準が共有されていない現状 がうかがえる。 また，実務上の問題を教育機関で教え ることの困難さ，技術者教育の中で倫理問題を扱うこ との困難さなども指摘されている。これらは, 視聴覚 教材等の不足の指摘とあわせ, 技術者倫理教育の主た る目的としての分析力・判断力をどのように育成すべ 
きか, という課題に対して, 未だ試行錯誤の段階であ る現状を示しているものと思われる.

3. 2 EAC (Ethics across the Curriculum) の構築 に向けて

（1）EACの意義と現状

実施状況からうかがえるように，技術者倫理教育は 知識を与えるだけでなく，実際の問題状況を分析し， 主体的に判断する能力の育成を目指すものと考えられ る. したがって, 単一の科目のみでこれを達成するこ とが困難であることは容易に推察できる。 そこで有効 と思われるのが，教育課程全体を通じた倫理教育，す なわちEAC (Ethics across the Curriculum) である. $\mathrm{EAC}$ 構築の可能性に関する設問（問11）では，「実践 可能(実践済み含む)」との意見が $1 / 3$ 超えており,「可 能であるが困難を伴う」,「多くの困難を伴うが実践に 努力すべき」を合わせると，90\%以上がEACの実践 について肯定的に捉えている（図 4).

既に実践しているとの回答は 3 件 $(4.7 \%)$ にとど まるが, 図 1 にも示したように, 複数科目において倫 理的内容を扱っている教育機関もある。この場合，理 工系科目（基礎科目および専門科目）の中で取り上げ ている教育機関が多い（問 6 (1))。いずれにせよ，カ リキュラム全体で，また複数科目で技術者倫理教育を 実施するとなると, 科目間の調整が必要となると思わ れるが, 取りまとめを行うコーデイネーターがいると ころは全体の $24 \%$ 程度であり, また, 実際の調整につ いてもシラバス等で授業内容について確認するという 程度に留まっているのが現状である（問 6 (4)).

(2) EAC実践における問題および実現に向けた課題

EACの実践が困難あるいは不可能であると考える 理由に関する回答（問12）からは，教育機関全体での EACの意義の認識がいまだ不十分であることがわか る。また，EACに限らず，教育課程全体を通じた共 通の目標達成に向けた取組みを従来の教育機関が十分

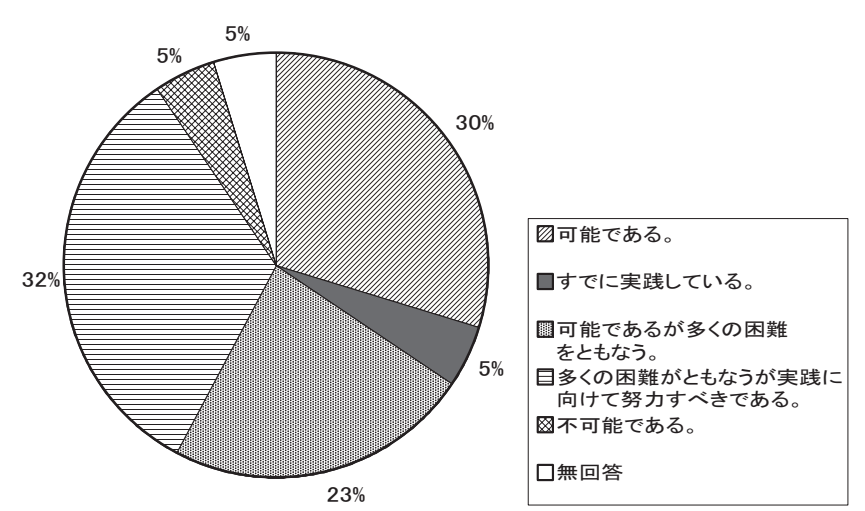

図 4 EAC の可能性について
には行ってきていなかったということがうかがえる.

EACを実現するにあたっての必要とされることに ついて問うた設問（問13）に対する回答から抽出され る課題として, EACについて教育機関全体での理解 を得ることがまず挙げられる，技術者倫理関連科目を 開設する実際上の理由としてJABEEへの対応という 回答が多かったが，それゆえ，JABEEへの関心が低 いところでは, 倫理教育に対する関心も低く, 倫理系 の科目が開設されていればそれで十分であるという意 識があるように思われる。したがって，EAC実現の ためには，1）技術者倫理が工学の中核にあるという ことを理解する，2)教養科目, 専門科目にかかわらず, 教員が技術者倫理教育の重要性についての共通理解を もつ, ということが重要であると思われる，その上で, 全学的な技術者倫理教育の体制を整えるために，次の ような課題が挙げられている。1）FD等の実施によ る教員の意識改革，2）EAC実施に向けた全学的な カリキュラムの検討・調整を行うための組織づくり, あるいはコーディネーターの確立，などである．また， EACに限らず，技術者倫理教育の実践にあたっては， 次のような課題・要望も挙げられている。1）教育内 容の標準化，2）事例の分析と情報の共有化，3）教 育教材の開発, などである.

EACに限らず, 近年特に議論されている, コミュ ニケーション能力, エンジニアリング・デザイン等を 含めた, 技術者教育の再構築が必要であるとの指摘も なされている.

\section{4. 結論}

今回の調査はInterest Groupメンバーを対象として 行ったものであるため, 日本の工学系教育機関一般に 関する現状として理解することはできない。しかし， 技術者倫理教育の重要性についての認識が高まってお り，また多くの教育機関で実践されているということ が把握できた。しかし, 同時に教育評価の方法や基準 など，実践にあたっての問題が明らかとなった，また， より効果的な倫理教育を実践するために，EACを構 築することが強く望まれている. 日本工学教育協会に 対する要望と併せ, 今後の課題であろう.

\section{謝辞}

本報告をまとめるにあたり, 独立行政法人科学技術 振興機構「社会技術研究システム公募型プログラム」 として平成16年度に採択された「Ethics Crossroads の形成と科学技術倫理の構築」(研究代表者札野順) の支援を受けた，関係各位に感謝します。 


\section{資料 調查結果報告}

問 1 貴教育機関において技術者倫理を扱う科目を開講していますか.
\begin{tabular}{|l|l|r|r|}
\hline & 開講している. & 件数 & 割合 \\
\hline 2 & 開講していない.今後も開講の予定はない. & 61 & $95.3 \%$ \\
\hline 3 & 現在は開していないが, 講して講の淮をしている. & 2 & $3.1 \%$ \\
\hline & 無回答 & 1 & $1.6 \%$ \\
\hline 合計 & 64 & $0.0 \%$ \\
\hline
\end{tabular}

問 2 開講していない理由をお答えください(複数回答可).

\begin{tabular}{|c|c|c|c|}
\hline & & 件数 & 割合 \\
\hline 1 & 適当な担当教員が確保できないため & 1 & $33.3 \%$ \\
\hline 2 & JABEEへの対怘に過ぎないと判断しているため & 0 & $0.0 \%$ \\
\hline 3 & 技術者教育と倫理教育はなじまないため & 0 & $0.0 \%$ \\
\hline 4 & 倫理教育は高等教育の中で行うのは難しいため & 0 & $0.0 \%$ \\
\hline 5 & カリキュラム上の制約で，新たな科目を開講する余裕がないため & 2 & $66.7 \%$ \\
\hline 6 & その他 & 1 & $33.3 \%$ \\
\hline & 無回答 & 0 & $0.0 \%$ \\
\hline
\end{tabular}

問 3 開講の理由を以下からお選びください(複数回答可).

\begin{tabular}{|c|c|c|c|}
\hline & 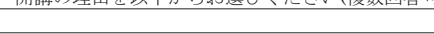 & 件数 & 割合 \\
\hline 1 & 技術者にとって不可欠な能力であるため & 51 & $83.6 \%$ \\
\hline 2 & 社会人として倫理観が重要であるため & 32 & $52.5 \%$ \\
\hline 3 & JABEEへの対応のため & 45 & $73.8 \%$ \\
\hline 4 & 技術者の倫理観が社会的に問題となっているため & 25 & $41.0 \%$ \\
\hline 5 & 国内の他の教育機関でも実施しているため & 2 & $3.3 \%$ \\
\hline 6 & 国際的な動向であるため & 6 & $9.8 \%$ \\
\hline \multirow[t]{2}{*}{7} & その他 & 3 & $4.9 \%$ \\
\hline & 無回答 & $\frac{0}{0}$ & $0.0 \%$ \\
\hline 合言 & & 61 & $100.0 \%$ \\
\hline
\end{tabular}

問 4 技術者倫理科目の実施形態についてお答えください.

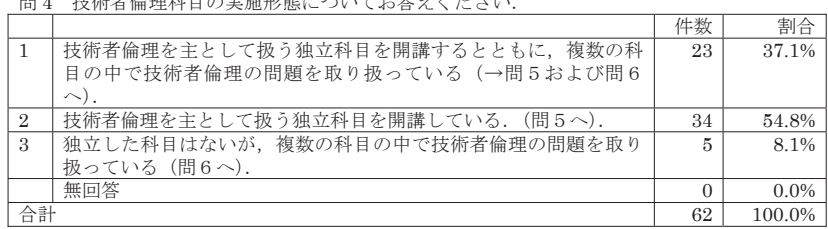

問 5 技術者倫理を主として扱う科目についてお答えください

(1) 開講形態についてお答えください.

\begin{tabular}{|l|l|r|r|}
\hline & \multicolumn{1}{l|}{} \\
\hline 1 & 必修 & 件数 & 割合 \\
\hline 2 & 選択 & 38 & $61.3 \%$ \\
\hline 3 & その他 & 14 & $22.6 \%$ \\
\hline & 無回答 & 5 & $8.1 \%$ \\
\hline 合計 & 5 & $8.1 \%$ \\
\hline
\end{tabular}

（2）当該科目の履修が推奨されている学年についてお答えください.

(2) 当該科目の履修が推奨されている学年についてお答えください.
\begin{tabular}{|l|r|r|r|}
\hline & 年次 & 件数 & 割合 \\
\hline 1 & 年次 & 8 & $12.9 \%$ \\
\hline 2 & 2 年次 & 10 & $16.1 \%$ \\
\hline 3 & 年次 & 26 & $41.9 \%$ \\
\hline 4 & 年次 & 9 & $14.5 \%$ \\
\hline 5 & その他 & 11 & $17.7 \%$ \\
\hline & 無回答 & 6 & $9.7 \%$ \\
\hline 合計 & 62 & $100.0 \%$ \\
\hline
\end{tabular}

(3) 開講期間についてお答えください.

\begin{tabular}{|l|l|r|r|}
\hline & & 件数 & 割合 \\
\hline 1 & 通期科目 & 5 & $8.1 \%$ \\
\hline 2 & 半期科目 & 45 & $72.6 \%$ \\
\hline 3 & 集中講義 & 4 & $6.5 \%$ \\
\hline 4 & その他 & 3 & $4.8 \%$ \\
\hline \multicolumn{1}{|c|}{ 無回答 } & 6 & $9.7 \%$ \\
\hline 合計 & 62 & $100.0 \%$ \\
\hline
\end{tabular}

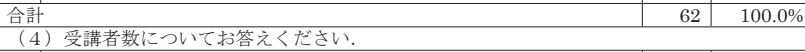

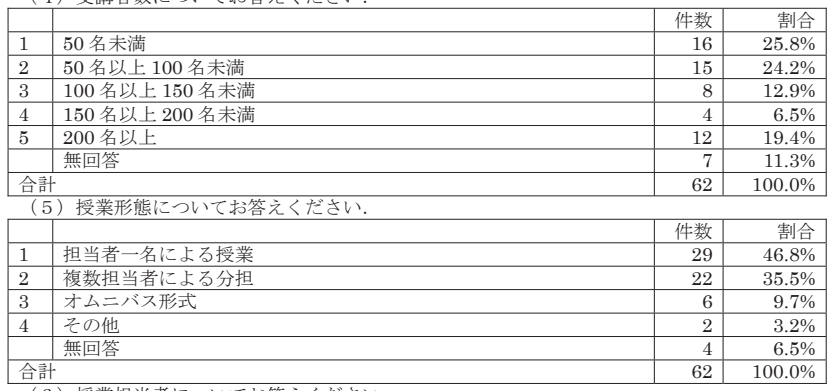

(6) 授業担当者についてお答えください.

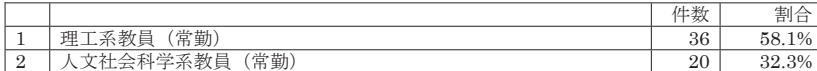

\begin{tabular}{|l|r|r|r|}
\hline 2 & 人文社会科学系教員 (常勤) & 20 & $32.3 \%$ \\
\hline 3 & 理工系教貝 $($ 他教育機関からの非常勤) & 3 & $4.8 \%$ \\
\hline & 人 & 1 & $1.6 \%$ \\
\hline
\end{tabular}

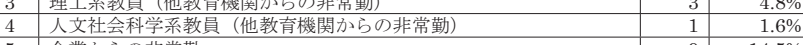

\begin{tabular}{ll|r|r|}
\hline 5 & 企業からの非常勤 & 9 & $14.5 \%$ \\
\hline 6 & その他 & 10 & $16.1 \%$ \\
\hline
\end{tabular}

\begin{tabular}{|l|r|r|}
\hline 無回答 & 10 & 4 \\
\hline 合計 & 62 & $6.5 \%$ \\
\hline
\end{tabular}

(7) 該当科目の学習・教育目標の設定方法についてお答えください(複数回答可)。

\begin{tabular}{|l|r|r|r|}
\hline & 割合 \\
\hline 1 & 大学・学部・学科などの教育目標との整合性を考慮して設定してい & 30 & $48.4 \%$ \\
\hline
\end{tabular}

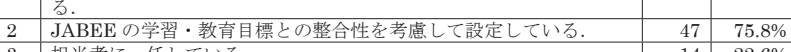

\begin{tabular}{l|r|r|r}
\hline 3 & 担当者に一任している. & 14 & $22.6 \%$ \\
\hline
\end{tabular}

\begin{tabular}{|l|r|r|r|}
\hline 4 & 教務委員会などで検討した上で，設定している. & 9 & $14.5 \%$ \\
\hline 5
\end{tabular}

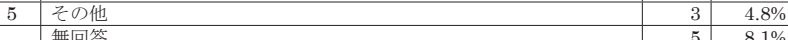

合計
(1) どのような科目のなかで技術者倫理の問題を报っていますか(複数回答可)

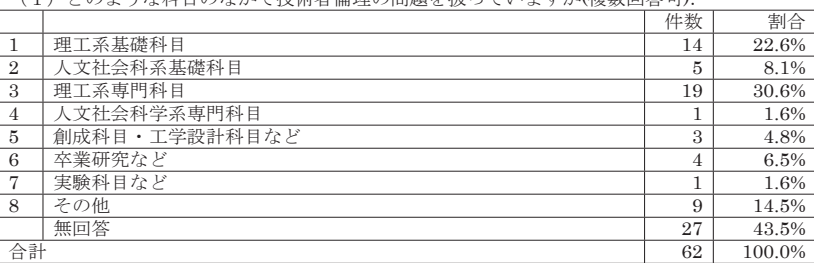

(2) 関連科目をとりまとめる担当者（コーディネーター）がいますか。

\begin{tabular}{|l|l|r|r|}
\hline & \multicolumn{1}{|c|}{ 件数 } & 割合 \\
\hline 1 & いる $(\rightarrow(3)$ へ) & 15 & $24.2 \%$ \\
\hline 2 & いない $(\rightarrow(4)$ へ) & 23 & $37.1 \%$ \\
\hline 3 & その他 & 3 & $4.8 \%$ \\
\hline \multicolumn{2}{|c|}{ 無回答 } & 21 & $33.9 \%$ \\
\hline 合計 & 62 & $100.0 \%$ \\
\hline
\end{tabular}

(3) 担当者（コーディネーター）についてお答えください.

\begin{tabular}{|l|r|r|r|}
\hline & & 件数 & 割合 \\
\hline 1 & 理工系教員(常勤) & 11 & $73.3 \%$ \\
\hline 2 & 人文社会科学系教員 (常勤) & 2 & $13.3 \%$ \\
\hline 3 & 理工系教員(他教育機関からの非常勤) & 0 & $0.0 \%$ \\
\hline 4 & 人文社会科学系教員 (他教育機関からの常勤) & 0 & $0.0 \%$ \\
\hline 5 & 企業からの非常勤 & 0 & $0.0 \%$ \\
\hline 6 & その他 & 5 & $33.3 \%$ \\
\hline & 無回答 & 1 & $6.7 \%$ \\
\hline 合計 & 15 & $100.0 \%$ \\
\hline
\end{tabular}

その他 : 委員会等の組織で調整を行っている 等

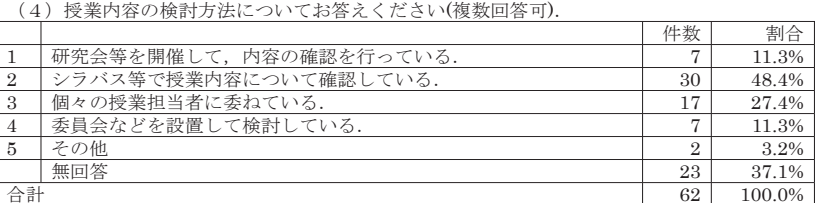

問 7 技術者倫理科目の授業方法についてお答えください(複数回答可).

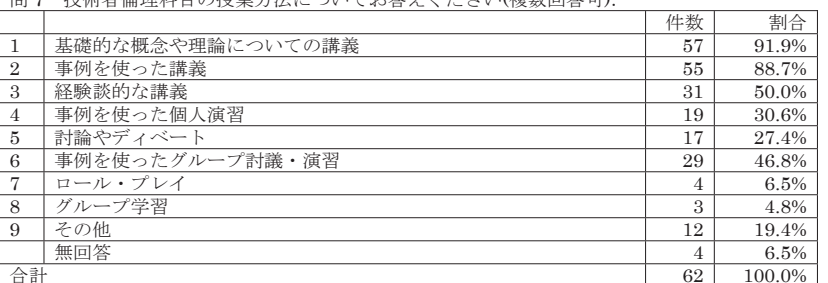

【全授業時間に対する上記授業方法の割合】

\begin{tabular}{|c|c|c|c|c|c|c|c|c|c|}
\hline & 1 & 2 & 3 & 4 & 5 & 6 & 7 & 8 & 9 \\
\hline & 件数 & 件数 & 件数 & 件数 & 件数 & 件数 & 件数 & 件数 & 件数 \\
\hline $10 \%$ 未満 & 1 & 0 & 4 & 1 & 3 & 5 & 0 & 0 & \\
\hline $10 \%$ 以上, $20 \%$ 未満 & 7 & 2 & 14 & 7 & 9 & 5 & 3 & 1 & 5 \\
\hline $20 \%$ 以上， $30 \%$ 未満 & 11 & 15 & 8 & 6 & 3 & 9 & 0 & 2 & 1 \\
\hline $30 \%$ 以上， $40 \%$ 未満 & 13 & 19 & 3 & 3 & 1 & 4 & 1 & 0 & 0 \\
\hline $40 \%$ 以上， $50 \%$ 未満 & 11 & $\begin{array}{lll}7 \\
\end{array}$ & 0 & 0 & 1 & 2 & 0 & 0 & 0 \\
\hline $50 \%$ 以上, $60 \%$ 未満 & 5 & 3 & 0 & 0 & 0 & 3 & 0 & 0 & \\
\hline $60 \%$ 以上, $70 \%$ 未满 & 5 & 4 & 0 & 0 & 0 & 0 & 0 & 0 & 0 \\
\hline $70 \%$ 以上, $80 \%$ 未満 & 1 & 2 & 0 & 0 & 0 & 0 & 0 & 0 & 0 \\
\hline $80 \%$ 以上, $90 \%$ 未満 & 1 & 1 & 0 & 0 & 0 & 0 & 0 & 0 & 0 \\
\hline $90 \%$ 以上 & 0 & 0 & 0 & 0 & 0 & 0 & 0 & 0 & 0 \\
\hline 無回答 & 2 & 2 & 2 & 2 & 0 & 1 & 0 & 0 & 3 \\
\hline 合計 & 57 & 55 & 31 & 19 & 17 & 29 & 4 & 3 & 12 \\
\hline
\end{tabular}

問 8 授業の中でどの上うな事例を用いていますか. 具体的に㧍答えください

詳細については割愛するが, 以下のような回答が寄せられた。

教科書等でよく取り上げられる事件・事故 : 複数回答のあったもの

チャレンジャー号爆発事故, シティコーブタワー, 東海村臨界事故, キルルベイン・ゴールド, ノト事件, 原発トラブル隐し, 航空機墜落事故 等

実際に生じた事件・事故：地下鉄サリン事件，信楽高原鉄道事故，チェルノブイリ事故， バート事件，化学工場爆発事故，薬害エイズ，サリドマイド，BSE，カビ取り凰，牛肉偽装 事件, ボパールの化学プラント毒ガス事故 等

問 9 成績評価についてお答えください

(1) 成績評価の方法について㧍答えください(複数回答可).

\begin{tabular}{|c|c|c|c|}
\hline & & 件数 & 割合 \\
\hline 1 & 筆記試験による評価を行っている. & 33 & $53.2 \%$ \\
\hline$\frac{1}{2}$ & レポートによる評価を行っている. & 48 & $77.4 \%$ \\
\hline 3 & 学習成果の発表による評価を行っている. & 13 & $21.0 \%$ \\
\hline 4 & 議論への参加状況等を考慮した評価を行っている. & 13 & $21.0 \%$ \\
\hline 5 & アンクートの実施による評価を行っている. & 2 & $3.2 \%$ \\
\hline \multirow[t]{2}{*}{6} & その他 & 12 & $19.4 \%$ \\
\hline & 無回答 & 2 & $3.2 \%$ \\
\hline 合言 & & 62 & $100.0 \%$ \\
\hline
\end{tabular}

(2) 成績評価の際の観点についてお答えください(複数回答可).

\begin{tabular}{|l|l|r|r|}
\hline & & 件数 & 割合 \\
\hline 1 & 偷理学などの基䃈知譏 & 24 & $38.7 \%$ \\
\hline
\end{tabular}

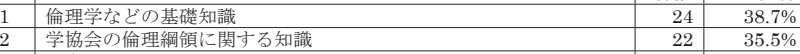

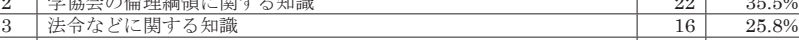

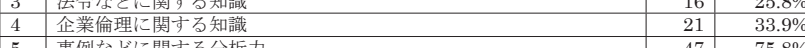

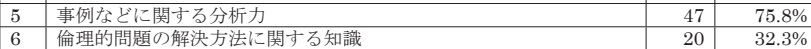

\begin{tabular}{l|r|r|r|}
\hline 7 & 倫理的問題解決に関するスキル & 20 & $32.3 \%$ \\
\hline & - & $24.2 \%$ \\
\hline
\end{tabular}

\begin{tabular}{|l|r|r|}
\hline 8 & 総合的な倫理的判断能力 & 33 \\
\hline
\end{tabular}

コミュニケーション能力 (文章表現カ, ブレセンテーション能力,

10 専門技術的知㜔

\begin{tabular}{r|r|r|}
\hline & 12 & $19.4 \%$ \\
\hline 無回答 & 4 & $6.5 \%$ \\
\hline 合計 & 62 & $100.0 \%$ \\
\hline
\end{tabular} 
問 10 授業を行う上での問題点をお答えください(複数回答可).

\begin{tabular}{|c|c|c|c|}
\hline & & 件数 & 割合 \\
\hline 1 & 教育機関内で担当教員を確保できない. & 12 & $19.4 \%$ \\
\hline 2 & 組織的な協力を得ることが難しい. & 8 & $12.9 \%$ \\
\hline 3 & 企業等の協力を得ることが困難である. & 1 & $1.6 \%$ \\
\hline 4 & 技術者教育において倫理の問題を扱うこと自体が難しい. & 10 & $16.1 \%$ \\
\hline 5 & 実務上の問題を学校教育で扱うことが困難である。 & 11 & $17.7 \%$ \\
\hline 6 & 他機関等の情報を知ることができない. & 6 & $9.7 \%$ \\
\hline 7 & 適切な教科書がない. & 8 & $12.9 \%$ \\
\hline 8 & 授業で扱うのに適当な事例が少ない. & 5 & $8.1 \%$ \\
\hline 9 & ビデオ等の視聴覚教材が不足している. & 24 & $38.7 \%$ \\
\hline 10 & 専門分野以外の内容を教えるのが難しい. & 7 & $11.3 \%$ \\
\hline 11 & 成績評価が難しい. & 29 & $46.8 \%$ \\
\hline 12 & 倫理観が備わったのかを判断することはできない. & 22 & $35.5 \%$ \\
\hline 13 & 学生の興味が薄い. & 12 & $19.4 \%$ \\
\hline \multirow[t]{2}{*}{14} & その他 & 10 & $16.1 \%$ \\
\hline & 無回答 & 5 & $8.1 \%$ \\
\hline \multicolumn{2}{|c|}{ 合計 } & 62 & $100.0 \%$ \\
\hline
\end{tabular}

問 11 日本の高等教育機関で $\mathrm{EAC}$ を実践することは可能だと思いますか

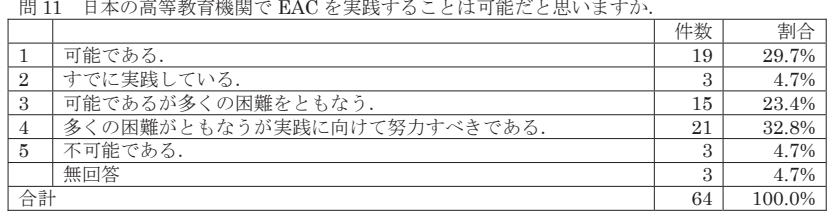

問 $12 \mathrm{EAC}$ の実践が困難あるいは不可能であると考える理由.

\begin{tabular}{|c|c|c|c|}
\hline & & 件数 & 割合 \\
\hline 1 & 教育組織全体で学習・教育目標などを設定することができないため & 10 & $25.6 \%$ \\
\hline 2 & $\begin{array}{l}\text { 技術者倫理だけでなく，教育課程を通して何か（例えば，コミュニ制がないため } \\
\text { ケージ教育するとうう能力） }\end{array}$ & 12 & $30.8 \%$ \\
\hline 3 & 工学系専門教員の主体的な参画を期待できないため & 11 & $28.2 \%$ \\
\hline 4 & $\begin{array}{l}\text { 大学, 学部, 学科などの組織単位で, コンセンサスを得られないた } \\
\text { め }\end{array}$ & 11 & $28.2 \%$ \\
\hline \multirow[t]{2}{*}{5} & その他 & 13 & $33.3 \%$ \\
\hline & 無回答 & 4 & $10.3 \%$ \\
\hline 合 & & 39 & $100.0 \%$ \\
\hline
\end{tabular}

(その他自由記述)

他にも教えなければならないので, 倫理教育だけを重視することは出来ない。

倫理教育の重要性についての認識が低い 等
問 13 日本の高等教育機関で EAC を実践するためには何か必要であるとお考えですか.ご自 由にご回答ください．

多くの回答が寄せられたが，主なものを以下に举げる。なお，内容的に重複したものについて は整理している。

- FD 等の取組により，教育機関全体での意識共有を行う。所属教員がこのような課題に関心 を持ち, 意義と必要性を理解し, 実践寸ることが必要。

・統一的教材の開発や評価の一限性の確保

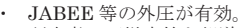

・研究者の不祥事等も報道されてお㧍り，研究者自身の倫理観を確立することが必要。

教員等（保護者も含めた大人）が，学生の行動の手本となることが必要 等

4.その他，技術者倫理教育についての抢考えをお聞かせください

多くの回答が寄せられたが，主なものを以下に挙げる。なお，内容的に重複したものについて は整理している。

・技術者教育において, 倫理教育は重要であり, 専門教育の要となるべき

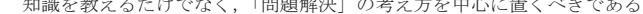

受講した学生の詊価も高い。失敗事例だけを扱うのではなく, 技術者の素晴らしさ, 意義等

・技術者倫理教育だけでなく, 教育全体の再構筑を行う必要がある 等

5. 技術者倫理教育について, 日本工学教育協会に期待することをお聞かせください,

多くの回答が寄せられたが, 主なものを以下に挙げる。なお，内容的に重複したものについて は整理している。

・ 日本の技術者教育に関してリーダーシップを発揮して欲しい

・ワークショップやシンポジウムの開催等, 情報交換や担当教員のスキルアップの場を提供し

教科書, 教育教材の開発・提供等

・学習・教育目標や教育内容, 評価方法等, ある程度標潐化された科目内容の提示

「工学」の新しい簡潔な定義を検討し, 提示して欲しい。

他の学協会との連携を図って欲しい。等 